The Quarterly Journal of Austrian Economics

Volume 22 | NO. 2 | 181-217 | SUMMER 2019 WWW.QJAE.ORG

\title{
Are Structural Fluctuations Natural or Policy-Induced? Analyzing Mises's and SCHUMPETER's CONTRibutions TO Business Cycle Theory
}

\author{
Bernardo Ferrero*
}

JEL Classification: B30, B31, B40, B41, E32, E51, O1, O3

\begin{abstract}
Aвstract: The 2007/8 financial crisis and economic recessions, much like the Great Depression of 1929, stimulated an increased interest in macroeconomics in general and business cycle theory in particular. Aside from a renewed interest in the various interpretations of Keynesianism, particular attention was devoted to the Austrian School. In the first half of the $20^{\text {th }}$ century within the broader Austrian camp there existed two well-established theories that, despite their important insights, were neglected by the mainstream economics profession. However, Joseph Schumpeter and Ludwig von Mises - both members of the third generation of Austrian economists-built theories of economic depressions that, despite presenting some similarities on some particular issues, were fundamentally telling a different story. A closer look at their overall theoretical system seems to suggest that their fundamental divergences have their origin in methodological and epistemological questions. Enamoured with static equilibrium analysis, Schumpeter was led to construct a theory of booms and busts that saw these as the natural outburst of a capitalist system that was inherently disruptive and unstable. Mises on the other hand, focusing on the dynamic market process, was led to conceive of booms and busts as the inevitable consequence of systematic intervention into capitalist production by the government and its corollary, the banking system.
\end{abstract}

*B Bernardo Ferrero (bernardo.96@hotmail.it) is a student at Universidad Rey Juan Carlos in Madrid. 


\section{INTRODUCTION}

With the creation of the Federal Reserve System in 1913, mainstream economists believed that financial panics had become a thing of the past. The central bank assumed the role of deviating the economy from overheating and undercooling: when prices seemed too low as to support business investments, the Fed was supposed to intervene by pumping money into the system and prevent prices from falling. On the other hand, in the case of inflation hysteria, it had to sell government bonds and suck money out of circulation. The ability to fine tune the economy through a combination of expansionary and contractionary monetary policies, reassured many economists that large economic fluctuations would disappear.

This general optimism found its clearest expression in the writings of Irving Fisher, precursor of monetarism. In 1925 Fisher argued that the fear of an upcoming bust was unwarranted: wholesale prices remained fairly stable, and general economic conditions did not allow for any downturn (Fisher 1925). This line of thought accompanied the American economist throughout the decade as he praised Benjamin Strong's credit expansion. "There may be a recession in stock prices, but not anything in the nature of a crash," he wrote in 1929 in response to the bearish predictions of financial advisor Roger Babson. As the stock market collapsed the following month, Fisher was proved wrong, and all of his portfolio was wiped out (Skousen 1993). He was not alone in his over-optimism regarding the state of the economy: along with Fisher were, among others, eminent academics like Wesley Mitchell—director of the New York's Bureau of Economic Research—and John Maynard Keynes. The latter, in particular stated, in 1927, "we will not have any more crashes in our time" (Skousen 2001, 327). The exuberant confidence in the American economy that academics had in the 1920's spilled over the political stage. Herbert Hoover, shortly before becoming president, declared that "we in America today are nearer to the final triumph over poverty than ever before in the history of any land...." (Hoover 1928, 35).

Prior to the Great Recession, things run on the same rails. As late as 2005, Milton Friedman (1912-2006) argued that "the stability of 
the economy is greater than it has ever been in our history. We really are in remarkably good shape. It's amazing that people go around and write story about how bad the economy is...." Similarly, Arthur Laffer, economic adviser under Reagan, responded to the bearish forecasts of economic analyst Peter Schiff, by saying: "I'll bet you a penny on this one... you are just way off base. There is nothing out there... we might be having a nice slowdown, but it's not going to be a crash" (Laffer, 2006). By December 2007, Friedman and Laffer's predictions were proved wrong: the bursting of the housing bubble led to the most pronounced meltdown since the Great Depression.

Just like in the aftermath of 1929, the inability of economists to predict the coming turmoil in 2008, brought business cycle theory back to the forefront of economics. The majority of economists has converged in the explanation of the crisis that sees de-regulation and the volatility of the capitalist system as the culprit. This line of thought has deepened interest in the demand-shock business cycle theories as put forth by Hicks and Hansen in their 1937 IS-LM model as well as in New Keynesian economics (Christiano 2017). Yet, despite Keynes's rise to prominence, this has not been the whole story. Distrust in the mathematical approach and in the attempt to reduce economics to a subset of the natural sciences, has also led to the revival of a paradigm that offers an alternative to the dominant Walrasian framework: the Austrian school (Neck 2014).

In the first half of the $20^{\text {th }}$ century, within the broader "Austrian camp", there existed two well-established business cycle theories which "the mainstream economics profession has chosen to ignore" (Ebeling 2010, 297). One refers here to the contributions of Joseph Schumpeter and Ludwig von Mises. Aim of the following paper is thus to lay down a comprehensive statement of these writer's theories, accounting for both their similarities and differences. For this purpose, the paper has been divided into three broad sections. In section one their figure will be presented against the background of the Austrian school, under whose influence both scholars began their studies; section 2 will outline their methodological foundations; section 3 will analyze their theory of economic depressions and draw the necessary conclusions. A recapitulation of the findings will end the paper. 


\section{MISES AND SCHUMPETER AGAINST THE BACKGROUND OF THE AUSTRIAN SCHOOL}

\section{Liberalism Revives Austrian Intellectual Life}

Ludwig von Mises and Joseph Schumpeter were born in the latter part of the $19^{\text {th }}$ century in what, after the 1866 Austro-Prussian war, became the Austro-Hungarian empire. The former in Lemberg and the latter in Triesch, both would soon leave their home and settle in Vienna: the major cultural centre of the old continent (Piombini 2017). This imperial city, in the decades which preceded the first world war, exemplified the achievements of classical liberalism (Raico 1992).

The establishment of classical liberalism in Austria began with the revolution of 1848. Before the 1850s minorities, which occupied certain geographical areas within the empire, were in the most parts confined to live within those areas, with their civil liberties being severely restricted. A case in point were the Jews who, up to 1848, were forbidden to own land in Vienna and to sojourn there for more than three days (Johnston 1981). Things began to turn around in the 1850s, and more importantly after 1866. The defeat at Königgratz ended with the failure of the Grossdeutsch solution. In the aftermath of the defeat, Franz Joseph (1830-1916) came to terms with the rising separatism emanating from the Magyar-dominated Hungarian provinces, by agreeing to the Ausgleich (Compromise) of 1867. The compromise consisted in the division of the emperor's territory into Hungary on the one hand, and a multi-ethnic region, Cisleithania, on the other. Apart from a common customs union, monetary system, foreign and military policies, Hungary was granted autonomy in domestic affairs.

Soon thereafter, the empire began to embark on the road of political and economic liberalization. A step in this direction was taken in 1861 with the establishment of estate parliaments, but what would change its fate in the half century to come was the introduction of a new liberal constitution on December 31, 1867, which outlined the Fundamental Law on the General rights of Citizens. From now onwards "every subject was secure in his life and private property; freedom of speech and the press was guaranteed; freedom of occupation and enterprise was permitted; all religious faiths 
were respected and allowed to be practiced; freedom of movement and residence within the empire was a guaranteed right; and all national groups were declared to have equal status before the law" (Ebeling 2010, 38). The 1867 constitution regenerated Austrian society, creating unprecedented opportunities for minorities within the empire-amidst which the Jews were by far the most prominent-to advance economically and socially (Schulak and Unterköfler, 2011).

Most significantly this liberal environment created the conditions for the revival of Austrian intellectual life. As Mises observed, "in the climate of freedom that these statutes warranted Vienna became a centre of the harbingers of new ways of thinking. From the middle of the sixteenth to the end of the eighteenth-century Austria was foreign to the intellectual effort of Europe. Nobody in Vienna-and still less in other parts of the Austrian Dominions - cared for the philosophy, literature, and science of Western Europe.... But when the Liberals had removed the fetters that had prevented any intellectual effort, when they had abolished censorship and had denounced the concordat, eminent minds began to converge toward Vienna" (Mises 1984, 10). It was amidst the late Habsburg milieu, that the major intellectual schools of the $20^{\text {th }}$ century were born. Throughout this period, Wittgenstein wrote his Tractatus Logico-Philosophicus; Mach built the foundations of logical positivism; Freud pioneered psychoanalysis and the study of the unconscious; Klimt gave birth to the secession movement in art and Carl Menger put Economics "on entirely new foundations" (Schumpeter 1969, 86).

\section{Menger and the Austrian School}

Menger's contributions to economic theory would forever characterize the distinctiveness of economists trained in the Austrian tradition. As Hayek stressed "[What] is common to the members of the Austrian school, what constitutes their peculiarity and provided the foundations for their later contributions, is their acceptance of the teaching of Carl Menger" (Hayek 1992).

At the time Menger was writing, throughout the continent, Economic Science was dominated on the one hand by the Anglo-Saxon school and its cost theory of value, and on the other 
by the rising scepticism and methodological holism of German Historicism. Menger's enterprise led to solve the problems associated with both traditions, by putting man at the centre. "Man himself" Menger stressed "is the beginning and the end of every economy" (Yagi 1993, 720-21). By stating this simple fact, he concluded that what gives an object a good's character is not some intrinsic feature, but its ability, in the eyes of the consumer, to satisfy a human need. Value is thus never independent of human consciousness and volition (Menger 1976).

What led classical economists like Smith and Ricardo to miss this point was a methodological error. They reasoned in terms of abstract classes, and not in terms of concrete quantities of goods and services exchanged by judging consumers. The latter-Menger realized-are never faced with a decision of exchanging classes of goods-milk, bread, diamonds-but rather to buy and sell given quantities-a gallon of milk, two pounds of bread, a carat of diamond - and their value is reflected by the importance that is placed on the (relevant) unit about to be acquired or given up. It is this unit that determines the value of all other units of a given supply. By focusing on the individual and his striving for the satisfaction of his needs, Menger became "the vanquisher of Ricardian theory" (Schumpeter 1969, 86).

The discovery of the law of marginal utility was simultaneously achieved by William Stanley Jevons (1870) in England and León Walras (1874) in Switzerland. Yet whereas Jevons and Walras were enamoured with the use of mathematics and functional analysis, Menger's approach ran through teleological and subjectivist lines. For Walras and Jevons, Economics, akin to mechanical physics, was a quantitative science, and thus required that its laws be mathematical. "As the complete theory of almost every other science involves the use of that calculus" Jevons wrote "so we cannot have a true theory of Economics without its aid. To me it seems that our science must be mathematical, simply because it deals with quantities" (Jevons 1970, 3). Of similar opinion was Walras, who went as far as constructing a theory of general equilibrium which reduced the market process to a system of simultaneous equations (Infantino 2002).

Menger had a different approach: the goal of economic science was not to build fictitious, mathematical models but to explain 
real world phenomena. As Lawrence White noted, "Rather than elaborating a system of timeless general equilibrium prices, which was the goal of the mathematical Walrasian system, Menger wanted to explain the forces and causes behind price formation" (White 2003, 9). Economics was for him a qualitative science: its scope was to discover and explain, by means of verbal logic, causal laws and for this purpose the use of mathematics was of no avail. As he wrote in a letter to Walras, "we do not simply study quantitative relationships but also the nature [or essence] of economic phenomena. How can we attain to the knowledge of this latter (e.g., the nature of value, rent, profit, the division of labor, bimetallism, etc.) by mathematical methods?" (Hutchison 1973, 17). In order to attain such knowledge, an economist had to employ an analytic-compositive method, which traced "the complex phenomena of the social economy to the underlying atomistic forces at work" (Jaffé 1976, 521). Menger understood the difference that separated him from the other "marginalists", and did not hesitate to end his epistolary exchanges with Walras, arguing that "a conformity does not exist between us. There is an analogy of concepts in a few points but not in the decisive questions" (Antonelli 1953, 284).

Despite Menger's revolutionary ideas, his Grundsatze had little impact on the German speaking world, due to the influence of the German Historical School of Wilhelm Roscher (1817-94), Bruno Hildebrand (1812-78) and Karl Knies (1821-98). Common to the members of this school was some sort of scepticism toward universal and time independent laws of economic activity (Cachanosky 2018, 251). This belief was derived from the fact that historicism "understood the world of man as a result of history.... All institutions, activities and events are put into their historic constellations and are thus unique. It is, therefore, impossible for man, and for human phenomena to follow fixed unchanging laws because everything depends on everything else and the world changes all the time" (Hauser 1988, 537). This scepticism reached its apex with the rise of Gustav Schmoller as leader of the school's second generation. Schmoller and his followers ruled out the possibility of universal laws of social reality: every observable regularity, they contended, was the product of the social institutions prevailing in a specific context (Hülsmann 2007, 122). They 
denied even the validity of such principles as the laws of supply and demand- and treated economics "as a historical and practical discipline" (Gordon 1993, 8).

Given the mild reception of his Principles, Menger set out to write a second book with the aim of clearing economics from unsound methodological foundations. The result was Investigations into the Method of the Social Sciences with Special Reference to Economics (1883) which presents an articulate defence of the "analytic-compositive" method in arriving at "exact laws": laws that are valid irrespective of time and place simply because they reflect the essential nature of the factors involved. Not surprisingly, it provoked irritation on the part of his adversaries, such that in the same year, Schmoller wrote a scathing review of the book, denouncing the Austrian Economist of having engaged in "aimless abstractions." With his response to Schmoller, Menger (1884) gave officially birth to the methodenstreit. Here the "matter in dispute was... whether there could be such a thing as a science, other than history, dealing with aspects of human action" (Mises 1984, 12).

\section{Mises and Schumpeter: The Third Generation}

Menger's Principles was initially intended to be the first of a four-volume treatise in economic theory. This project, however, was never realized by Menger himself, and the development of the Austrian paradigm was a task that fell on the shoulders of his major disciples, Eugen von Böhm-Bawerk (1851-1914) and his brother in law, Friedrich von Wieser (1851-1926). The framework that the Galician nobleman built, however, proved to be the essential starting point from which these two thinkers took off (Ebeling 2016).

Thanks to their publications, by the mid 1880s the Austrian tradition flourished into a school of thought (Kirzner 2001). Not only did their writings find fertile soil in Austria, but also in other parts of the world, as soon as their works appeared in English in the beginning of the 1890s. By the time that Mises and Schumpeter entered the University of Vienna in the early 1900s, the Austrian School was one of the five major schools of economic thought 
competing for professional influence, with many of its core ideas being absorbed by the mainstream (Kirzner 2001). ${ }^{1}$

Schumpeter entered the University of Vienna's law faculty in 1901. Born in Triesch on February 8, 1883, Jozsi witnessed the premature death of his father-a rich textile manufacturer-at the age of four, and soon moved with his mother Johanna Gruener (1861-1926) to live in Graz. Here the two remained from 1888 to 1893, until Joanna married Sigismund von Kéler, a retired general from the Austro-Hungarian army. Thanks to the high status of his stepfather, upon settling with his family in Vienna, from the age of ten to eighteen Schumpeter attended, as a day student, the Theresianum, one of the most favored high schools by the Viennese aristocracy, and which "left an important imprint upon his personality" (Haberler 1950, 335). While his classical education was formed during his years at the Theresianum, it was upon entering University that Schumpeter was introduced to economics by Friedrich von Wieser, who had inherited Menger's chair of political economy in 1903.

Mises entered the University of Vienna's Faculty of Law around the same time, in 1900. He was born in Lemberg on September 29, 1881, son of Adele Laundau (1858-1937) and Arthur Edler von Mises (1854-1903), "a very well-to-do railroad enterpriser," whose Jewish family had been ennobled the day of Mises's birth (Kuehnelt-Leddihn $1999,1)$. Young Ludwig began his primary studies in Lemberg but, as soon as the father was assigned an important post with the ministry of railways, by 1892 the he moved to Vienna and was sent to the Academische Gymnasium. (Shulak and Unterköfler, 2011). During his years at the Gymnasium - Vienna's most prestigious school along with the Theresianum and the Schottengymnasium - he was imparted a classical education and began to cultivate his early interests in political history. By the time he finished his studies, however, Mises became disillusioned with the historical method and, feeling more attracted to problems of economic and social history, decided to study law

\footnotetext{
${ }^{1}$ When sociologist Albion Woodbury Small visited Menger in Vienna in 1903, the latter confessed to him that "It is entirely indifferent to me whether the name Austrian School be preserved. The important thing is that every economist worthy of the name has now virtually adopted every essential thing that I stood for" (Small 1924, 173).
} 
(Mises 2009, 1-2). Under the direction of Karl Grünber-a member of the German Historical School and follower of George Friedrich Knapp-his major works during this period were on history, not on theory. Things, however, changed in 1903. "Around Christmas, 1903," Mises recalled in his memoirs, "I read Menger's Grundsätze der Volkswirtschaftslehre for the first time. It was the reading of this book that made an 'economist' of me" (ibid.25).

The two met during these years. In 1904, after resigning as third-time finance minister to the Austrian government, BöhmBawerk was conferred an exclusive professorship at the University of Vienna's law faculty. Soon after settling his new chair Böhm began to hold a prestigious Privatseminar that attracted the most eminent intellectuals of the time. Aside from Mises and Schumpeter, participants included Felix Somary, Richard von Strigl, and a group of important Marxists like Nicolai Bukharin, Rudolph Hilferding, Otto Bauer and Emil Lederer (Streissler 1990). "The opening of BöhmBawerk's seminar," Mises commented years later, "was a great day in the history of the University of Vienna and in the development of economics" (Mises 2009, 31). Apart from the lively discussions between the Böhm-Bawerkians and the Austro-Marxists, here "the contrasting stands of Mises and Schumpeter surfaced, a contrast that had its apparent roots in their different personalities no less than in their substantive disagreements on methodological and theoretical issues" (Vandberg 2015, 92). Personality-wise, the two could not have been more different: whereas Schumpeter emerged in the classroom "as the man of paradox... toying with ideas, now arguing their merits and then attacking them viciously," Mises developed "the imperturbable intransigence of his lucid thinking" that will forever characterize his persona (Allen 1991, 39; Rueff 1994).

With regards to theoretical issues these differences were not any milder. While Mises was a declared follower of BöhmBawerk, Schumpeter found closest affinity to Walras and Wieser (Schumpeter 2010). While the latter had in his first years receptively absorbed Menger's principle of marginal utility he "completely ignored the structure of reality-based price theory that Menger had laboured to build upon it" (Salerno 1999, 37). In the decades leading up to World War I, as a result of his widely-shared achievements, Schumpeter became the leading figure in the Austrian school, with his book Das Wesen having a definite impact on the fourth generation 
(Morgenstern, 1976). Mises's rise to prominence would, instead, have to wait. "That they had one of the great thinkers... in their midst" Hayek observed, "the Viennese have never understood" (Hayek 1977 in Mises 2009, xx).

\section{ON METHOD}

If one seeks to understand the theoretical differences that separate the two most prominent members of the third generation of Austrian economics, and in specific their trade cycle theories, one cannot avoid looking at their methodological underpinnings. In the case of Schumpeter, the question of method "is the necessary starting point for an interpretation of his views" (Roncaglia 2005, 420). The same is true of his contemporary, for whom questions of method are foundational to any search for scientific truth.

\section{Methodological Tolerance and Positivism}

While Schumpeter is often remembered for his sociological studies, his first works as an economist dealt with issues of methodology and epistemology. The work that introduced him to the profession, was a study, published in 1906, on the importance of the mathematical method in economic theory, which demonstrated the influence that the study of this literature had on his thinking. Already from this early paper, the reader is able to grasp how, despite being raised against the background of the Viennese school, he was "far more attracted by the views of such as Cournot, Jevons, Edgeworth, Marshall and Walras" (Schneider 1951, 54).

While his 1906 article introduced him to the field of academia, it was Das Wesen, published at the age of twenty-five, that gave Schumpeter international fame and which made him into the youngest professor of political economy in the empire and the leading figure of the Austrian school's third generation. In Das Wesen, one is presented with "Schumpeter's first analysis and statement of the economy's nature and the methods and theories with which to study it" (Allen 1991, 74). Its purpose was "to dissect as exactly as possible the basis, the methods, and the main findings of pure economics in order to gauge its nature, its value, and its 
potential for further development." The focal point of his exposition is the static economy, a framework "wherein all economic quantities subsist in changeless, mutually determined general equilibrium" (Schumpeter 2010; Salerno 1999, 39). All throughout, the book "breathes the spirit of Lausanne rather than Vienna" (Schneider 1951, 54).

What emerges in this treatise is what Fritz Machlup calls "methodological tolerance." At a time in which the mind set of most professors continued to be steeped in the methodenstreit, the young economist emphasized that "we should abstain from claiming "general validity" or superiority for any method" (Machlup 1951, 146) Such a view, most probably, Schumpeter inherited it from the Theresianum where students were taught that "One should know the rules of all parties and ideologies, but not belong to any party or believe in any one opinion" (Swedberg 1991, 12). The correct method, he argued, depends on the concrete problem one is faced with explaining. One must not fall in the erroneous conclusion that methodological disputes can be settled a-priori (Schumpeter 2010, 14). This, which he calls "the pragmatic approach," requires that "The description of the method... not be the first chapter but rather the last one." Schumpeter's methodological liberalism, has pushed Roncaglia to parallel his views with the epistemological relativism of Kuhn, Lakatos and Feyerabend. Similarly, Samuelson has gone all the way to define the Austrian economist, an "eclectic methodologist." (Roncaglia 2005; Samuelson 1982, 4).

Despite his arguments against methodological absolutism, from the beginning Schumpeter had strong convictions regarding the nature of economics and its affinity with the natural sciences. Economics, was a science in his view, in the way in which Ernst Mach, intended it to be, that is relying on external observation as the basis for its scientific propositions. This stance earned him the fame as "the first real positivist among economic theoreticians" (Hülsmann 2007, 167). "For Schumpeter," Hülsmann explains, "the only basis for scientific propositions was observation of the exterior world. And the only suitable method of economic theory was to follow the approach that had proven successful in the natural sciences. In short, he was a positivist who believed that the only method that could yield "facts" was observation of the exterior world" (Hülsmann 2007, 166). Foreshadowing Milton 
Friedman (1953), the great admirer of Walras insisted, in fact, that economic theorems are neither realistic nor a priori. They are at best hypothetical statements based upon arbitrary assumptions which, although being detached from economic reality, are tools that allow to deal with a wide range of economic phenomena. Thus, for example, the law of subjective marginal value is to be regarded not as a law, but as a hypothesis that enables the economist to explain price phenomena in a more satisfactory way than the old cost-of production theories. It is irrelevant, according to Schumpeter, whether the assumptions upon which theories are built and the theories themselves are realistic and true. Just like a tailor's skirt is judged according to how well it fits his customers, theorems are to be accepted on the grounds of whether they are able to fit with the facts. It on this basis that one must accept the general-equilibrium model (Schumpeter 2010, 386).

Another aspect which is worth pointing out with regards to Schumpeter's positivist methodology, concerns his emphasis on the quantitative aspect of Economics. Exemplary on this note are the words with which he addressed the Econometric Society in 1933: "We do not impose any credo-scientific or otherwise-, and we have no common credo beyond holding: first, that economics is a science, and secondly, that this science has one very important quantitative aspect." A few lines ahead, he went as far as to contend that in "one sense... economics is the most quantitative, not only of 'social' or 'moral' sciences, but of all sciences, physics not excluded... There would be movement even if we were unable to turn it into measurable quantity, but there cannot be prices independent of the numerical expression of every one of them, and of definite numerical relations among all of them" (Schumpeter, 1933: 69). This emphasis on Economics as a quantitative science reflects the influence Cournot, Edgeworth, Jevons, but most importantly Walras had on his thinking, an influence which, all throughout his life, outstripped that of the Austrians. Paul Samuelson, himself student of Schumpeter at Harvard, recalls that "In his general views on economic theory, he seemed surprisingly un-Austrian. On the whole, he was much more Walrasian. He always referred to León Walras as by far the greatest economist of all time" (Samuelson 1951, 103).

In line with his intellectual predecessors, Schumpeter, starting in his early works, presented as the focal point of economic analysis 
the exchange relationship between autonomous quantities of goods. His was an attempt to recast economic analysis along the line of classical mechanics, which implied relegating purposeful human behaviour to the background. As Kirzner explains, "In economics, Schumpeter explains, we have economic quantities of goods undergoing mutually determined exchanges that admit of being expressed by means of mathematical functions... It is the existence of these functional relationships between all these quantities that makes economic science possible. Indeed, it is these relationships themselves that constitute the whole of the subject matter of that science" (Kirzner 1976, 69).

\section{Apriorism, Praxeology and Methodological Dualism}

In contrast to his contemporary, Ludwig von Mises constructed a theory of economics built upon Menger's subjectivism. In the process of constructing a coherent analytical framework, the Austrian economist relied on a purely theoretical method, stressing the a priori nature of economic laws. Unlike Schumpeter who, in light of his instrumentalism came to the conclusion that methodology should be relegated to the last chapter, methodological and epistemological issues occupied the first 143 pages of Human Action (Mises 1998). The recognition of the importance of method in the development of a logically coherent theory, however, was not inborn. In his early years, as earlier noted, Mises was entrenched in historicism, believing there could be no scientific discipline outside of economic history. "I saw no possibilities for economic science when I entered the university.... I believed that there was nothing in economic life that could be made the object of scientific analysis outside of economic history. There could not have been a more consistent follower of historicism than I" (Mises 2009, 104). The reading of Menger broke the cohesiveness of this epistemological position but overall the writings of the methodenstreit did not satisfy him and in order to be at peace with himself he assumed that problems of methodology were of secondary importance: priority was to be given to the advancement of science. He soon, however "recognized the error of this stance. With each problem, the economist confronts the basic questions: whence do these principles come, what is their significance, and how do they relate to 
experience and "reality"? These are not problems of method or even research technique; they are themselves the fundamental questions. Can one construct a system of deduction without having asked the questions upon which the system is to be built?" (Mises 2009, 105). With this rhetorical question in mind, Mises set to disclose the nature, scope and validity of Economic knowledge, first with a series of essays epitomized in Epistemological problems of Economics (1933) and later, with Theory and History (1956) and The Ultimate Foundation of Economic Science (1962).

The starting point for an analysis of Mises's epistemological and methodological positions must be the Vienna Circle of the 1920's, who's tenets he rejected (Gordon, 1994). The Vienna circle was founded by Moritz Schlick (1882-1936) and consisted of a group of philosophers who professed the ideas of logical positivism, a creed which found its roots in the classical empiricism of John Locke and David Hume. Members of the group included Otto Neurath, Rudolf Carnap, Felix Kauffmann and among others even Richard von Mises and Karl Menger, respectively Mises's brother and Menger's son. The central and unifying idea of these logical positivists was that knowledge about the real world is attainable only via observational experience; any proposition, therefore, that is not empirically verifiable, is either tautological or nonsensical (Ayer 1946, 2). As Gordon put it, "The essence of logical positivism can... be quite simply stated. All empirical statements, i.e., statements about the world, must be testable. If a statement cannot be tested, then it has no empirical meaning.... Only propositions that can be both true and false, depending on circumstances, convey information. Propositions that either must always be true or must always be false do not" (Gordon 1996, 33). Nothing about reality, therefore, can be known with a priori certainty.

Mises developed his ideas against the backdrop of logical positivism, upholding economics as an example of a science based upon what Kant called synthetic a priori propositions-statements that are known to be true without the need for empirical verification and that, at the same time, convey new knowledge about the world (Hoppe 1995). According to Mises, the logical positivist's claim that no empirically meaningful knowledge is to be found outside sensory experience, was ultimately self-contradictory, for this very same claim was unverifiable. "There is an obvious objection against 
this doctrine, viz., that this proposition that there are no synthetic a priori propositions is in itself a-as the present writer thinks, false-synthetic a priori proposition, for it can manifestly not be established by experience" (Mises 1962, 4). For Mises, that nothing about reality could be known with certainty, was ultimately refuted by what he called the action axiom. That humans act, that they employ subjectively chosen means for the attainment of subjectively chosen ends, was, he contended both meaningful and self-evident.

The axiom action, became the starting point for all economic analysis. Every action, Mises showed, involves selecting and setting aside, i.e. choosing, something which in order to manifest itself presupposes the existence of scarcity-the fundamental economic condition. On the basis of this recognition, Mises rooted economic theory in the broader science of human action: Praxeology. The purpose of an economist, he contended, is to study the categories implied in this axiom and deduce from these the entire corpus of economic theory. To the extent that they "represent the elucidations of the fact that man acts," the principles he arrives at, come to have a similar status to the laws of mathematics and logic. Provided that they are the result of correct deductive reasoning they are both "aprioristically true and apodictically certain" (Boettke 2012, 206). "Its statements", Mises wrote with reference to praxeology, "are, like those of logic and mathematics, a priori. They are not subject to verification or falsification on the ground of experience and facts" (Mises 1962, 32). The Austrian economist thus echoed Menger (Herbener 1991; Gordon 2012), who against the positivists of his day argued, "Testing exact theory of economy... is simply a methodological absurdity... a process analogous to that of the mathematician who wants to correct the principles of geometry by measuring real objects" (Menger 1985, 69-70).

If Schumpeter claimed that economic propositions are hypothetical, Mises treated Economics as an axiomatic-deductive science. But the differences do not end here. More fundamentally, unlike his contemporary for whom economic theory consisted of "a box of tools" (Schumpeter 2006, 15), Mises viewed economics as that science which unveils the causal laws that govern social reality. The fact that its principles are non-hypothetical in no way prevent them from furnishing knowledge about reality. "The theorems attained by correct praxeological reasoning are not only perfectly certain and 
incontestable.... They refer, moreover, with the full rigidity of their apodictic certainty and incontestability to the reality of action as it appears in life and history. Praxeology conveys exact and precise knowledge of real things" (Mises 1949, 39).

Mises's methodological apriorism rested on the conviction that a categorical difference exists between the natural and social sciences, something that empiricists à la Schumpeter denied. While in sciences like physics or chemistry the subject matters are inanimate objects, in the social sciences the subject matter is man, with his goals, preferences and his ability to reason, think, and learn from experience. This difference has important implications. The first one is that Man's free will inhibits the ability of the researcher to conduct controlled experiments and to stipulate quantitative laws regarding given relationships. The second is that being an actor himself, the social scientist is "at the outset of his researches already in possession of the ultimate principles governing the phenomena which form the subject of his study, whereas mankind has no direct knowledge of ultimate physical principles. Herein lies the radical difference between the social sciences (and moral sciences, Geisteswissenschaften) and the natural sciences. What makes natural science possible is the power to grasp or to comprehend the meaning of human action" (Mises 1990, 9). To such an extent, physics and economics, required different methods: this he called methodological dualism.

Economics, however, was not the only branch of the social sciences: no less important was history. Even these two disciplines, however, were in Mises's view different in nature. The former studies the necessary implications of the fact that humans act; action is seen exclusively in its general, essential form, and the principles that are logically deduced are true of any action. The mental tool of such a discipline is "conception." On the other hand, history, studies action in its concrete manifestations: its scope is not the general, but the disclosure of the particular and the individual. The mental tool of history is "understanding" (Ferrero 2018). In disagreement with Schumpeter, Mises contended that no historical investigation could be set forth without the aid of theoretical propositions as delivered by Economics. "History must rest on theory, not to alienate itself from its proper tasks, but on the contrary, in order more than ever to discharge them in the true sense of history" (Mises 1962, 136). 


\section{ENTREPRENEURS, B ANKERS, AND BUSINESS CYCLES}

Our discussion of Schumpeter and Mises's role within the Austrian school and our examination of their respective methodological approaches, feeds into the central problem of economics: the theory of why cyclical fluctuations occur in capitalistic economies. In the case of Schumpeter, the argument was first put forward as part and parcel of a more general theory of progress: his trade cycle theory appeared as the last chapter of The Theory of Economic Development (Schumpeter 1991). Briefer presentations were then conveyed to the English world with the publication of two essays in the late 1920s, The Explanation of the Business Cycle (1927) and The Instability of Capitalism (1928). Mises's theory on the other hand resulted from the application of Menger's subjective theory of value to the fields of money and banking. It is in his The Theory of Money and Credit that one finds the building blocks of the Austrian Theory of the Business Cycle; its essence was then refined and restated in Monetary Stabilization and Cyclical Policy (Mises 1912; 1928). Both economists attempted, in their respective books, to tackle a macroeconomic phenomenon by formulating an analysis that took into consideration the dynamic microeconomic processes that drive the market economy. In their discontent with traditional neoclassical economics both Mises and Schumpeter could be said to have been on the same page. Yet, despite converging on these ideas, the two economists tell very different stories, a difference that can be found in their respectively Walrasian and Austrian training. Following Ludwig Lachmann (1966, 553-54) one can say that the core difference between these two approaches to economic theory and reality lies in the fact that "The validity of the Lausanne model is limited to a stationary world. The background of the Austrian theory, by contrast, is a world of continuous change in which plans have to be conceived and continually revised."

\section{The Insufficiency of Static Analysis}

As earlier noted, in Das Wesen (1908) Schumpeter familiarized the German public with the general equilibrium model as set forth by Walras. After publishing the book, therefore, he made sure to 
write his maestro a letter where he promised him a copy in so far as he described himself as a "disciple" and his work an "homage" (Schumpeter 2000, 43). The copy of Das Wesen soon arrived, and one year after the publication of the book, Schumpeter decided to pay his great mentor a visit. At the time of his travel, Schumpeter had in mind of writing a book that, while departing from the set of facts characteristic of the static economy, explained how the economic system itself would generate economic development and while conversing with Walras came to see a deficiency in his analysis that would forever characterize his thinking. Not only-he realizedwas Walras's representation of the economy entirely static-in that the method of analysis relied on a general equilibrium model-but his analysis only explained a stationary economy for in his eyes the economy "does not change of its own initiative, but merely reproduces constant rates of real income as it flows along in time" (Medearis 2009, 42).

More specifically, what Walras told Schumpeter was that "economic life was essentially passive and merely adapts itself to the natural and social influences which might be acting upon it, so that the theory of a stationary process constitutes really the whole of theoretical economics and that as economic theorists we cannot say much about the factors that account for historical change, but must simply register them". This view Schumpeter found to be profoundly unsatisfactory. As he put it: "I felt very strongly that this was wrong, and that there was a source of energy within the economic system which would of itself disrupt any equilibrium that might be attained" (Schumpeter 1989, 166). This endogenous source of energy that continuously revolutionised the economic structure, became a central theme in Schumpeter's works. According to him, in fact, one failed to understand modern capitalism without an analysis of dynamic processes, for "Capitalism... is by nature a form or method of economic change and not only never is but never can be stationary" (Schumpeter 1942, 82).

\section{The Banker, the Entrepreneur and the Will to Lead}

How to link the logic of pure economics with the world of dynamic processes, was a problem he set forth to resolve in his Theory of Economic Development. Here "Schumpeter's aim was to create an 
organic link between the circular flow and the description of development" (Madarász, 1980: 346). His, was an attempt to explain the process of economic change by considering general equilibrium as the starting point and end of his analysis. This had to be the sequence of his explanation, for it was the only one consistent with his Walrasian conviction that equilibrium represented a real state of affairs. As Rothbard noted, "To set forth a theory of economic change from a Walrasian perspective, Schumpeter had to begin with the economy in a real state of general equilibrium. He then had to explain change, but that change always had to return to a state of equilibrium, for without such a return, Walrasian equilibrium would only be real at one single point of past time and would not be a recurring reality" (Rothbard 1989, 263).

The circular flow which Schumpeter explains in great detail in the first chapter, represents an economic system, based on private property and freedom of exchange, that constantly reproduces itself. Its main feature is the absence of action, replaced as it were by "a changeless and unending round of robotic behaviour" (Rothbard 1989, 261). Individuals are faced with perfect certainty and no knowledge imperfection, responding as mere objects to the prevailing state of affairs and to the given set of tastes, techniques and resources. Consumers are sovereign, and production merely replicates consumer desires through time. As one would expect in world of no uncertainty, no space is left for neither profits nor losses: all sale receipts are fully absorbed, due to the law of imputation, by land and labour, in the form of wages and rents. Herein lies a twist in the standard analysis of general equilibrium that plays a crucial role in his theory. Under the influence of J.B. Clark, Schumpeter came to minimize the role of time in production: in equilibrium, he argued, production and consumption would be synchronized. The result was to claim that, along with residual incomes being zero, even interest had no reason to exist in the circular flow: not only the entrepreneur — the residual claimant—but also the capitalist—-the interest bearer-was removed.

In the circular flow, where "routine and custom provide the motive force for business behaviour," Schumpeter admitted of the possibility for quantitative growth; this however was not to be mistaken for development (Heilbroner 1988, 169). "Development in our sense is a distinct phenomenon, entirely foreign to what may 
be observed in the circular flow or in the tendency toward equilibrium. It is spontaneous and discontinuous change in the channels of the flow, disturbance of equilibrium, which forever alters and displaces the equilibrium state previously existing" (Schumpeter 1991, 64). The source of this disruption was to be found in technological progress. Population and capital growth, while possibly a manifestation of development did not constitute its engine. Similarly for consumer tastes. Schumpeter was not of the idea that consumers had the power of actively directing production. Rather it was the other way around. "The large flock of consumers does not drag forward production, on the contrary, those who dominate production... lead the consumers" (Schumpeter 1910, 74).

Technological progress consists in bringing about "new combinations": new products, new production methods, new markets, new source of supplies or new organizational forms. The carrying out of new combinations is the manifestation of economic development, and its driving force is the entrepreneur (Schumpeter 1991, 74). These individuals, who bring innovations and move the economy beyond equilibrium, are not in any meaningful sense normal. They are "a special breed as different from the rest of mankind as grey hounds are from poodles," for they, unlike the rest, have the will to move beyond the confines of the static world, governed by tradition, custom and experience (Hülsmann 2007, 172). In so doing they are leaders in the process of social change. "Schumpeterian entrepreneurs" observes Ferlito, "not only bring out new combinations, driving economic change; they are, also and above all, leaders able to master economic change, to dare where normal individuals stop, facing social and economic opposition and finally winning their challenge" (Ferlito 2016, 49).

One can understand the difficult in mastering the process of change, by looking at what Schumpeter considers three obstacles that drivers of change must inevitable face. Firstly, drivers of change must face uncertainty which makes the formulation of plans much harder for the economic subject. Secondly, while a new thing is not objectively harder, it is psychologically so. Last but not least, during a process of change, there is a tendency for the social environment to react against a person who wants to embark in innovation. It is in light of these three fundamental obstacles that one can deduce that, whomever actually carries out new combinations and masters 
a process of economic change, is ultimately a true and proper social leader. In his essay "The Instability of Capitalism" (1928, 379), Schumpeter, in fact, clarified that "Successful innovation is... a task sui generis. It is a feat not of intellect, but of will. It is a special case of the social phenomenon of leadership". As a consequence, it is not surprising to realize that what fundamentally motivates all entrepreneurs is then, for Schumpeter (1911), not monetary profit, but three psychological desires: the dream of founding a kingdom; the will to win and the joy of creating. One can thus agree with Stephan Boehm $(1990,225)$ that "the picture of the Schumpeterian entrepreneur... is one of strong-willed men with vision; men of true gift defying 'the persistence of the old regime'... and ready to take on the world."

The way these entrepreneurs are able to embark upon their disruptive projects is by bidding away the means of production from their current employments and recombine them into new and better ways. A problem, however seems here to arise. For if in the circular flow all business revenues are absorbed by production costs, how do entrepreneurs gather the necessary purchasing power to redirect resources to their new ambitious plans? Here, to rescue the entrepreneur, appears the figure of the banker, with his newly created cash ready to be loaned out. With this new credit, entrepreneurs receive the necessary buying power to outcompete the managers of the circular flow and re-deploy existing means of production so as to develop new combinations. For this reason, the banker is an essential component in the process of capitalistic development. He is to be regarded, in Schumpeter's eyes, as "the ephor of the exchange economy", for with his inflationary credit "he makes possible the carrying out of new combinations, authorises people, in the name of society as it were, to form them" (Schumpeter 1991, 74).

\section{Booms and Busts as Stages of Development}

This process of disequilibrium set in motion by the entrepreneur and the banking system and the consequent cluster of innovations represents the boom period of Schumpeter's cycle theory. As the innovative entrepreneur capitalizes on his new production technologies, he is, in fact, able to create for himself an opportunity 
for profit by exploiting a temporary divergence between input and output prices. After the pioneer has, using Kirzner's (1973, 70) expression, "blazed new trails," however, he attracts, like a magnet, imitators who are intent upon further exploiting these new profit opportunities created by these innovations. The entry of these second wave of innovators forces profits back to zero: one the one hand the increased demand for labour and land increases the prices of these factors, and therefore the costs of production, and on the other the increased supply pushes output prices down. In the meanwhile, as the new firms start reaping profits the old firms which have clung to older methods of production start making losses and declaring bankruptcy, and as the initial successful firms start repaying their debts, a general period of deflation ensues. As the innovations are completed and inefficient firms readjust to the new circumstances, the economy reaches a new equilibrium state that leaves it prepared for a subsequent wave of innovations. The depression in Schumpeter's framework represents this inevitable, natural readjustment of the economy to the changing conditions brought about by the introduction of novel combinations on the part of entrepreneurs.

This interesting point elicits a few considerations. The first is that one is faced here with "a picture of both progress and fluctuation - a theory of development which is also a theory of the trade cycle" (Robbins 1968, 16). This idea was effectively summarized by Schumpeter $(1942,132)$ in his later book Capitalism, Socialism and Democracy: "the function of entrepreneurs is to reform or revolutionize the pattern of production by exploiting an invention or, more generally, an untried technological possibility for producing a new commodity or producing an old one in a new way, by opening up a new source of supply of materials or a new outlet for products, by reorganizing an industry and so on... This kind of activity is primarily responsible for the recurrent "prosperities" that revolutionize the economic organism and the recurrent "recessions" that are due to the disequilibrating impact of the new products or methods." The second, linked to the latter, is that capitalist evolution necessarily creates by its own, natural impetus the conditions for a period of depression to occur: attempting to correct this phase, ultimately, represents an attempt to pervert capitalism itself. 


\section{Mises: Problems with Mainstream Monetary Theory}

The point of departure for Mises's business cycle was not a theory of economic development, but a theory of money. Since the days of David Ricardo, it became standard procedure, to separate the micro side of the economy from the macro part. Accordingly, the price of money, was explained by reference to a mechanical version of the quantity theory. Mises, then set out, in his Theory of Money and Credit, to solve this futile divide and present a macroeconomic theory grounded in microeconomic decisions.

Grounding his analysis on individual action, the Austrian economist gave a causal-realist explanation of how the value of money is determined and how variations in the quantity of a medium of exchange has repercussions on the real economy. Regarding the former contribution, Mises showed that, just like with any other economic good, the price of money is determined by the interaction of suppliers and demanders in the market. This argument had historically been dismissed: explaining the price of money by appealing to demand and supply analysis was considered to be prey of logical circularity, because of the nature of money as a medium of exchange. This, Mises showed, however was not so: one could still say that the demand for money is based on the price and that the price of money is dependent upon its demand by taking into account the "time dimension of the problem" (Rothbard 1989, 13). "For the solution of this problem," he wrote, "we refer to the purchasing power of the immediate past, of the moment just passed. These are two distinct magnitudes. It is erroneous to object our theorem... that it moves in a vicious circle" (Mises 1949, 405-06).

Regarding the second problem-that of the quantity theoryMises showed how an increase in the money supply occurs at a given time and place, and therefore cannot homogenously affect individual economic agents in the same way, as was thought by John Stuart Mill (1983). As money pours into the economy it affects certain prices and incomes first, distorting production in those particular markets and later making its way throughout the economy (Mises 1953). The negation of monetary neutrality was to form the basis of his cycle theory. According to Hayek, who in the 1930s would make further contributions in this field, "this distortion of the whole price structure" brought about by the inflationary process represents "the 
fundamental point which the master of all of us, Ludwig von Mises, has never tired from emphasizing" (Hayek 1970, 96).

\section{Circulation Credit and Intertemporal Discoordination}

Fundamental to a comprehension of Mises's analysis is the separation between "Commodity Credit" and "Circulation Credit." In analyzing the field of banking, Mises realized that these institutions perform two distinct, social functions. The first one is that of warehouse for people's deposit. Given the risk of storing cash in one's house, or of conducting business with money on hand, merchants would find it convenient to deposit their money proper with an entrusted banker who would then, in exchange of a fee, credit them with a demand deposit, a money substitute which they could then use for their daily transactions. Note that, in this scenario, while there has been a change in the composition of money, its total supply has remained unvaried: while checking accounts have increased, this increase has been accompanied by a proportional reduction in the amount of physical cash. The second major function that banks perform is that of credit intermediation whereby the bank acts as middleman between the economy's savers and investors, profiting from an interest rate differential. Even in this case, the activity of the bank does not result in an increase in the total money supply: whatever is lent to the bank represents resources saved up for investment purposes by the community. This is the essential nature of "commodity credit."

While these two banking activities, if kept logically apart, are socially useful in their own right, their combination creates the condition for the emergence of "circulation credit", the engine that sets in motion the business cycle. What happens in this scenario is that the bank begins to treat its demand deposits, entrusted by its customers for safekeeping, as available savings to be lent to the public, by creating bank notes and/or demand deposits unbacked by an increase in reserves. These are then lent to willing borrowers, who embark upon investible projects. Whereas in the first case, however, the money lent to the borrower represented a claim on goods that the public- by curtailing their consumption- had willingly saved up for the purpose of such investment, this time no curtailment of consumption on the side of the public took place: 
"an act of new 'investment' can occur that is independent of any increased voluntary 'savings'” (Ebeling 2010, 291).

In order to entice new borrowers to take on additional loans, the bank must accommodate these new checking accounts at lower interest rates than otherwise, so as to make marginal projects look profitable. These marginal projects tend, according to Mises to be those that are further removed in time from present consumption, for "the sensitivity of a project's profitability to the interest rate is directly related to its duration" (Murphy 2015, 252). Projects that require capital to be tied up for a long period of time get an artificial boost when the interest rate is lowered, and this incentivises entrepreneurs to engage in long-term capital intensive investments. The market interest rate, thus, in the Misesian framework, "coordinates production across time" (Woods 2009, 67). Consumer's decision of how to allocate their spending decision between the present and the future gets reflected in the amount of savings they provide to the community. The relative scarcity / abundance of these savings which arise from people's present to future consumption ratios, is then communicated to the business community via the interest rate: a high interest rate indicating a low willingness to defer consumption into the future, while a lower one denoting more future-orientedness. Based on this interest rate, entrepreneurs make calculations that guide them to align their inter-temporal production decisions with the inter-temporal consumption preferences of the public.

If an increase in loanable funds however, is not a reflection of people's higher willingness to save, but the consequence of "circulation credit" emitted by the banks, alignment between savers and investors gets distorted. While entrepreneurs are induced to expand the economy's capital structure and engage in long-term projects that will bear fruit in the more distant future, consumers have not decreased their levels of current consumption. This discoordination, sets in motion a trajectory whereby the economy is pulled contemporaneously into the direction of more consumption and more investment, an unsustainable path that ultimately has to be reversed (Ritenour 2010, 369-70). "Resource scarcities... eventually turn boom into bust" (Garrison 2001, 72). In Nationaloekonomie Mises $(1940,523)$ would thus conclude that "What is viewed as bad in an economic downturn are the effects coming into play of the consequences of an artificial boom fuelled by credit expansion." 


\section{The Entrepreneurial Class as a Mistaken Master Builder}

The insufficiency of available resources to complete all the long-term projects that entrepreneurs have undertaken manifests itself in an increase in the price of consumer goods relative to those of producer goods, and to the re-establishment of a higher interest rate. These changes turn what were considered profitable endeavours into losing economic propositions. Many businesses shut down, while others scale back production and lay off workers. This is the beginning of the recession. Its source is not the insufficiency of aggregate demand, but the "unsustainable" boom driven by the easy money policy of the banking system, which has misled entrepreneurs to invest in overly ambitious plans and to underinvest in shorter production processes that consumers desired the most. A recession, according to Mises, represents therefore a healthy correction, that pushes businessman to stop their wasteful activities and reallocate their available factors of production in line with the most urgent wants of consumers. A recession, one can say, reflects the reassertion of consumer sovereignty across the structure of production.

To show the nature of the boom as involving Malinvestment, and the role of the recession as a healthy liquidation of past mistakes, Mises uses the example of a master builder as a representative agent of the entire business community, who, in misjudging the amount of resources available at hand, advises an overly ambitious construction plan that cannot be completed. "The whole entrepreneurial class is, as it were, in the position of a master-builder whose task it is to erect a building out of a limited supply of building materials. If this man overestimates the quantity of the available supply, he drafts a plan for the execution of which the means at his disposal are not sufficient. He oversizes the groundwork and the foundations and only discovers later in the progress of the construction that he lacks the material needed for the completion of the structure. It is obvious that our master-builder's fault was not overinvestment, but an inappropriate employment of the means at his disposal" (Mises 1949, 556-57).

\section{Proximate Similarities, Fundamental Differences}

In both business cycle theories, a crucial role is played by the banking system. It is the newly created credit on the part of the banker, lent to 
entrepreneurs, that in both scenarios gives birth to the euphoria of the boom, and ultimately to the inevitable ensuing of a crisis. Furthermore, in both theories, recessions represent healthy readjustment processes that need not be interfered with, in order to guarantee the possibility for future economic development. In Schumpeter's story, however, economic crises are seen as endemic to capitalism, while for Mises they result from tampering with the market economy.

This fundamental divergence derives from the basis upon which their theories are built. Schumpeter departs from a general-equilibrium framework and attempts from there to account for change. Given the constraints of the circular flow, change, he concludes, can only originate from heroic entrepreneurs who, financed by inflationary bank credit, impose their will on consumers and disturb the underlying market structure. Mises's theory, on the contrary, is based not on a world of equilibrium (non-action), but in one of disequilibrium (action). Change is there from the start as resourceful entrepreneurs strive, under uncertainty, to adjust production-with the help of money prices-toward the satisfaction of consumer wants. Consumer sovereignty, not innovationism, is for him the fundamental aspect of Capitalism (Knox 2005).

It is true that even the latter employs the concept of the evenly rotating economy - which denotes a self-reproducing economy-but the purpose of this concept is not, as for Schumpeter to represent an underlying reality, but "merely to provide a point of departure for construction of a realistic theory" (Hérbert 1988, 128). What needs explanation is how structural maladjustments between inter-temporal consumer preferences and inter-temporal production processes can occur, and to the extent that the market tends to weed out bad entrepreneurs, business cycles must come from non-market forces. Whereas the introduction of loanable funds unbacked by savings thus represents the only logical way of accounting for capitalist evolution in Schumpeterian economics, according to Mises, it represents a violent distortion of the inherent coordinative character of the market process.

\section{CONCLUSION}

This paper began with the climate of freedom that pervaded Vienna throughout the second half of the $19^{\text {th }}$ century, and which 
created the conditions for cultural and intellectual advancement. A case in point was the Austrian School, born from the innovative pen of Carl Menger, whose approach radically differed both from the anti-theoretical positions of the German Historical School, and the quantitative economics of Jevons and Walras. Menger was then succeeded by Böhm-Bawerk and Wieser, who seized upon their teacher's main contributions. Notwithstanding their reception of his message, these two members of the second generation were different in significant ways, and these differences shaped the main figures of the Third Generation: Mises and Schumpeter.

Trained under Böhm-Bawerk, Mises professed the a priori character of economic theory, the insufficiencies of induction, and the relevance of Economics for disclosing the cause and effect relationships that govern the real world. Schumpeter, on the contrarywho "felt closest to the works of Walras and von Wieser" - employed a positivist methodology, emphasized the quantitative nature of Economics and expressed faith to the general equilibrium model. Their methodological differences, as has been shown, ultimately surface in their respective accounts of why structural fluctuations appear in capitalist economies. Here the points of agreement, are surpassed by their divergences not in number, but in essence. To be sure, as both writers touch on very similar issues: the importance of the banking system and its artificial credit expansion in the boom period; the dynamic role of the entrepreneur in bidding resources from other uses; the inherently readjusting character of recessions and the need for re-equilibration. Attesting the similarity on these points is the fact that Mises himself, in 1931, praised Schumpeter's book as one of the four top contributions in the German language (McCaffrey 2014).

Notwithstanding its merits, however, according to Mises Schumpeter's Theory of Economic Development was "a typical product of his equilibrium theory" (Mises 2009, 28). Understanding the insufficiency of static analysis-which had only explained how things worked in a stationary setting-Schumpeter set himself the task of disclosing the dynamics of a changing economy. While the end of his research had changed, the means with which he embarked on such project, however, remained unvaried. Wanting to remain faithful to the model of his "great teacher" — which obliged him to view general-equilibrium as the ordinary state of affairs-he 
formulated a story that began in a state of rest. Soon, by the union of heroic entrepreneurs and ingenious bankers, this state of rest was disturbed, only to be eventually replaced by a new one. In this story, the boom phase of the business cycle is associated with the initial disturbance, while the struggling to reach a new state of rest is representative of the depression. Development and business cycles are inseparable phenomenon.

In Mises's theory, capitalist development and business cycles are not inseparable. The latter, in fact, is to be considered as the negation of the former. Basing himself on the theory of action as it manifests in the real world, the fundamental aspect of capitalistic development is not, for him, the introduction of technological innovations and the disruption of equilibrium, but production, on the side of risk bearing entrepreneurs, to meet consumers most urgent desires. The alignment between entrepreneurial speculation and consumer satisfaction is made possible by the price system which, being a reflection of underlying scarcity conditions of goods and services, furnish producers with both the compass and incentive to act economically. While entrepreneurial decisions are forever bound by uncertainty, and therefore always susceptible to failure, the understanding of the market as having in-built mechanisms of adjustment, brought Mises to the conclusion that a cluster of errors can occur only when the price mechanism is tricked by the credit expansion of the banking system, creating a maladjustment between consumer's time preference and the structure of production.

\section{REFERENCES}

Allen, Robert L. 1991. Opening Doors: The Life and Work of Joseph Schumpeter, vol. 1. New Brunswick and London: Transaction Publishers.

Antonelli, Etienne. 1953. “Léon Walras et Carl Menger à travers leur correspondence." Economie Appliqée 6: 269-87.

Ayer, Alfred J. 1946. Language, Truth and Logic, rev. ed. Oxford: Oxford University Press.

Boettke, Peter J. 2012. Living Economics. Yesterday, Today and Tomorrow. Oakland, Calif.: Independent Institute. 
Bonar, James. 1888. "The Austrian Economists and Their Theory of Value." Quarterly Journal of Economics 3: 1-31.

Cachanosky, Juan Carlos. 2018. "La Escuela Austriaca de Economia." Pp. 247-73 in Lecturas de Pensamiento Economico. $2^{\text {nd }}$ ed., ed. Adrian Ravier. Madrid: Unión Editorial.

Christiano, Lawrence J. 2017. The Great Recession: A Macroeconomic Earthquake. Minneapolis: Federal Reserve Bank of Minneapolis. Accessed April 10, 2018. https:// minneapolisfed.org/research/economic-policy-papers/ the-great-recession-a-macroeconomic-earthquake.

Ebeling, Richard. 2010. Political Economy, Public Policy and Monetary Economics. New York: Routledge.

- 2016. Carl Menger and the Foundations of Austrian Economics. Fairfax, Va.: The Future of Freedom Foundation. Accessed April 4, 2018. https://www.fff.org/explore-freedom/article/carlo-menger-and -the-foundations-of-austrian-economics/.

Economist, The. 2016. "How Vienna Produced Ideas that Shaped the West." Accessed May 4, 2018. https://www.economist.com/news/ christmas-specials/21712044-city-century-how-vienna-producedideas-shaped-west-.

Ferlito, Carmelo. 2016. Hermeneutics of Capital: A Post-Austrian Theory for a Kaleidic World. New York: Nova Science Publisher.

Ferrero, B. 2018. "Ferlito versus the Austrian School." StoriaLibera: Rivista di scienze storiche e sociali 4, no. 7: 233-58.

Fisher, Irving. 1925. "Our Unstable Dollar and the So-Called Business Cycle." Journal of the American Statistical Association 20, no. 150: 179-202.

Friedman, Milton. [1953] 1966. "The Methodology of Positive Economics." In Essays in Positive Economics, ed. Milton Friedman. Chicago: University of Chicago Press.

- 2005. "Milton Friedman On Charlie Rose (Part One)." YouTube. Accessed April 5, 2018. https://www.youtube.com/ watch?v=nPHs9Ln8QT8.

Garrison, Roger. 2001. Time and Money: The Macroeconomics of Capital Structure. New York: Routledge. 
Gordon, David. 1994. "The Philosophical Contributions of Ludwig von Mises." Review of Austrian Economics 7, no. 1: 95-106.

- 1993. The Philosophical Origins of Austrian Economics. Auburn, Ala.: Ludwig von Mises Institute.

—. 2012. "Mises versus Menger?" Auburn, Ala.: Ludwig von Mises Institute. Accessed April 6, 2018. https://mises.org/library/ mises-versus-menger.

Haberler, Gottfried. 1950. “Joseph Alois Schumpeter, 1883-1950." Quarterly Journal of Economics 64, no. 3: 333-72.

Hauser, Karl. 1988. "Historical School and Methodenstreit." Journal of Institutional and Theoretical Economics (JITE) / Zeitschrift für die gesamte Staatswissenschaft 144, no. 3: 532-542.

Hayek, Friedrich A. [1970] 2012. "Can We Still Avoid Inflation?" In The Austrian Theory of the Trade Cycle and other essays, ed. Ludwig von Mises, Richard Ebeling, and Roger Garrison. Auburn, Ala: Ludwig von Mises Institute.

. 1992. "Carl Menger (1840-1921)." In The Collected Works of F.A. Hayek, Volume IV: The Fortunes of Liberalism: Essays on Austrian Economics and the Ideal of Freedom, ed. Peter G. Klein. Chicago: University of Chicago Press.

Hébert, Robert F., and Albert N. Link. 1988. The Entrepreneur: Mainstream Views and Radical Critiques. New York: Praeger.

Heilbroner, Robert L. 1988. Behind the Veil of Economics: Essays in the Worldly Philosophy. New York: W.W. Norton.

Herbener, Jeffrey. 1991. "Ludwig von Mises and the Austrian School of Economics." Review of Austrian Economics 5, no. 2: 33-50.

Hoppe, Hans-Hermann. 1995. Economic Science and the Austrian Method. Auburn, Ala.: Ludwig von Mises Institute.

Hoover, Herbert. [1928] 2000. "Presidential Nomination Address." In The Two Faces of Liberalism, ed. John Gray. Oxford: Blackwell.

Hülsmann, Jörg Guido. 2007. Mises: The Last Knight of Liberalism. Auburn, Ala.: Ludwig von Mises Institute. 
Hutchison. Terence W. 1973. "Some Themes from Investigation into Methods." Pp. 10-55 in Carl Menger and the Austrian School of Economics, ed. John R. Hicks and Wilhelm Weber. Oxford: Oxford University Press.

Infantino, Lorenzo. 2002. Ignorance and Liberty. Abingdon-on-Thames, U.K.: Routledge.

—. 2008. Individualismo, Mercato e Storie dell idee. Soveria Mennelli: Rubbettino.

Jaffé, William. 1976. "Menger, Jevons and Walras De-Homogenized." Economic Inquiry 14, no. 4: 511-24.

Jevons, William S. [1871] 1970. The Theory of Political Economy, 5th ed. New York: Augustus M. Kelley.

Johnston, William M. 1981. Vienna, Vienna: The Golden Age, 1815-1914. New York: C.N. Potter.

Kirzner, Israel M. 1973. Competition and Entrepreneurship. Chicago: University of Chicago Press.

- 1976. The Economic Point of View: An Essay in the History of Economic Thought. Kansas City: Sheed and Ward.

- 2001. Ludwig von Mises: The Man and His Economics. Wilmington: Intercollegiate Studies Institute.

Knox, F. 1960. "The Doctrine of Consumers' Sovereignty." Review of Social Economy 18, no. 2: 138-49.

Kuehnelt-Leddihn, E. 1999. The Cultural Background of Ludwig von Mises. Auburn, Ala.: Ludwig von Mises Institute.

Laffer, Arthur. 2006. "Peter Schiff was right 2006-2007- CNBC edition." YouTube. Accessed April 4, 2018. https://www.youtube.com/ watch?v=Z0YTY5TWtmU.

Machlup, Fritz. 1951. "Schumpeter's Economics Methodology." Review of Economics and Statistics. 33, no. 2: 145-51.

Madarász, A. 1980. "Economists and Economic Thought: Schumpeter's Theory of Economic Development." Acta Oeconomica 25, no. 3/4: 337-57.

McCaffrey, Matthew. 2014. "Mises and Schumpeter: Friendly Rivals?" Mises Institute. Accessed May 4, 2018. https://mises.org/library/ mises-and-schumpeter-friendly-rivals. 
Medearis, John. 2009. Joseph A. Schumpeter. New York: Continuum.

Menger, Carl. 1884. Die Irrthümer des Historismus in der deutschen Nationalokonomie Vienna: Alfred Holder.

- 1976. Principles of Economics. New York: New York University Press.

_ [1883] 1985. Investigations into the Methods of the Social Sciences with Special Reference to Economics. New York: New York University Press.

Mill, John S. [1848] 1983. Principi di economia politica, vol. 2. Turin: Utet.

Mises, Ludwig von. 1962. The Ultimate Foundation of Economic Science. Princeton, N.J.: Van Nostrand.

- [1928] 1978. "Monetary Stabilization and Cyclical Policy." Pp. 37-171 in Von Mises, On the Manipulation of Money and Credit, ed. Percy L. Greaves. Dobbs Ferry, N.Y.: Free Market Books.

__ [1912] 1981. The Theory of Money and Credit. Indianapolis: Liberty Classics. 1984. The Historical Setting of the Austrian School of Economics. Auburn, Ala.: Ludwig von Mises Institute.

—. 1990. "Social Science and Natural Science." Pp. 3-16 in Money, Method and the Market Process: Essays by Ludwig von Mises, ed. Richard M. Ebeling. Boston: Kluwer.

—. [1949] 1998. Human Action: A Treatise on Economics. Scholar's Edition. Auburn, Ala.: Mises Institute.

- [1957] 2007. Theory and History. An Interpretation of Social and Economic Evolution. Auburn, Ala.: Ludwig von Mises Institute.

—. 2009. Memoirs. Auburn, Ala.: Ludwig von Mises Institute.

Morgenstern, Oskar. 1976. “Joseph A. Schumpeter, 1883-1950." In Selected Economic Writings of Oskar Morgenstern, ed. Andrew Schotter. New York: New York University Press.

Mund, Vernon A. 1933. Monopoly: A History and Theory. Princeton, N.J.: Princeton University Press.

Murphy, Robert P. 2015. Choice, Cooperation, Enterprise and Human Action. Oakland, California: Independent Institute. 
Neck, Reinhard. 2014. "Austrian Economics Today." Atlantic Economic Journal 42: 121-22.

Piombini, Guglielmo. 2017. "Stefan Zweig e Il mondo di ieri." StoriaLibera: Rivista di scienze storiche e sociali 3: 6: 63-73.

Raico, Ralph. 1992. “The Rise, Fall and Renaissance of Classical Liberalism.” The Future of Freedom Foundation. Accessed May 4, 2018. https://www.fff.org/explore-freedom/article/rise-fall-renaissance -classical-liberalism-part-1/.

Ritenour, Shawn R. 2010. Foundations of Economics. A Christian View. Eugene, Ore.: Wipf and Stock.

Robbins, Lionel. 1968. The Theory of Economic Development in the History of Economic Thought. London: Macmillan.

Roberts, Russell. 2011. "Why Friedrich Hayek is Making a Comeback." Wall Street Journal. Accessed April 5, 2018. https://www.wsj.com/articles/ SB10001424052748704911704575326500718166146.

Roncaglia, Alessandro. 2005. The Wealth of Ideas. Cambridge: Cambridge University Press.

Rothbard, Murray N. 1988. Ludwig von Mises: Scholar, Creator, Hero. Auburn, Ala.: Ludwig von Mises Institute.

— [1989] 2011. "Breaking out of the Walrasian Box: The Cases of Schumpeter and Hansen." Pp. 261-77 in Murray Rothbard, Economic Controversies. Auburn, Ala.: Ludwig von Mises Institute.

Rueff, Jacques. 1994. “The Intransigence of Ludwig von Mises." In On Freedom and Free Enterprise: Essays in Honour of Ludwig von Mises. ed. M. Sennholtz. Irvington-on-Hudson, N.Y.: Foundation for Economic Education.

Salerno, Joseph. 1999. “The Place of Mises's Human Action in the Development of Modern Economic Thought." Quarterly Journal of Austrian Economics 2, no. 1: 35-65.

Samuelson, Paul A. 1951. "Schumpeter as a Teacher and Economic Theorist." Review of Economics and Statistics 33, no. 2.

1982. "Schumpeter as an Economic Theorist." Pp. 1-27 in Schumpeterian Economics, ed. Helmut Frisch. New York: Praeger. 
Schneider, Erich. 1951. "Schumpeter's Early German Works, 1906-1917." Review of Economics and Statistics 33, no. 2: 104-08.

Schumpeter, Joseph A. 1910. "Die neuere Wirtschaftstheorie in den Vereinigten Staaten. Schmollers Jahrbuch für Gesetzgebung." Verwaltung und Volkswirtschaft 34: 913-63.

—_. 1933. “The Common Sense of Econometrics." Econometrica 1, no. 1:5-12.

- [1911] 1934. The Theory of Economic Development. $2^{\text {nd }}$ revised ed. Cambridge, Mass.: Harvard University Press.

—. 1942. Capitalism, Socialism and Democracy, New York: Harper.

—. 1954. History of Economic Analysis, New York: Oxford University Press.

- 1969. Ten Great Economists: From Marx to Keynes. New York: Oxford University Press, p. 76-86.

_ [1928] 1989. “The Instability of Capitalism." Pp. 47-72 in Essays on Entrepreneurs, Innovations, Business Cycles, and the Evolution of Capitalism, ed. Richard V. Clemence. New Brunswick, N.J.: Transaction.

_ . [1937] 1989. "Preface to Japanese edition of 'Theorie der wirtschaftlichen Entwicklund."' Pp. 160-66 in Essays on Entrepreneurs, Innovations, Business Cycles, and the Evolution of Capitalism, ed. Richard V. Clemence. New Brunswick, N.J.: Transaction.

— . [1927] 1991. “The Explanation of the Business Cycle." Pp. 21-46 in Essays on Entrepreneurs, Innovations, Business Cycles, and the Evolution of Capitalism by Joseph A. Schumpeter, ed. Richard V. Clemente. New Brunswick, N.J.: Transaction.

Schumpeter, Joseph, and Bruce A. McDaniel. 2010. The Nature and Essence of Economic Theory. New Brunswick, N.J.: Transaction.

Schulak, Eugen-Maria, and Herbert Unterköfler. 2011. The Vienna of Ludwig von Mises. Mises Institute. Accessed April 4, 2018. https://mises.org/ library/vienna-ludwig-von-mises.

Skousen, Mark. 1993. "Who Predicted the 1929 Crash?" Pp. 247-84 in The Meaning of Ludwig von Mises, ed. Jeffrey M. Herbener. Amsterdam: Kluwer Academic Publishers.

- 2001. The Making of Modern Economics: The Lives and Ideas of the Great Thinkers. New York: M.E. Sharpe. 
Small, Albion W. 1924. Origins of Sociology. Chicago: University of Chicago Press.

Streissler, Erich W. 1990. Menger, Böhm-Bawerk and Wieser. The Origin of the Austrian School. Pp. 151-200 in K. Hennings and W.J Samuels, Neoclassical Economic Theory. Boston: Kluwer Academic Publishers.

Swedberg, Richard. 1991. Schumpeter: A Biography. Princeton: Princeton University Press.

Vandberg, Viktor. 2015. "Schumpeter and Mises as 'Austrian Economists."” Journal of Evolutionary Economics 25, no. 1: 91-105.

Walras, Léon. 2013. Elements of Pure Economics. Hoboken, N.J.: Taylor and Francis.

- 1965. Correspondence of Léon Walras and Related Papers, ed. William Jaffé. Amsterdam: North Holland.

White, Lawrence. 1977. The Methodology of the Austrian School Economists, Ludwig von Mises Institute. https://mises.org/library/ methodology-austrian-school-economists-0.

Woods, Thomas. 2009. Meltdown. New York: Regnery.

Yagi, Kiichiro. 1993. "Carl Menger's Grundsatze in the Making." History of Political Economy 25, no. 4: 720-21. 